\title{
未破裂脳動脈瘤
}

\author{
その新しい概念について
}

浅利 正二・山本 祐司

\section{New Category of Unruptured Cerebral Aneurysms}

\author{
Shoji ASARI and Yuji YAMAMOTO \\ Department of Neurological Surgery, Matsuyama Shimin Hospital, Matsuyama
}

\begin{abstract}
Thirty outpatients with unruptured cerebral aneurysms were screened by noninvasive cerebral computed angiotomography at Matsuyama Shimin Hospital between 1979 and 1984. Seventeen were male and 13 were female. The ages at diagnosis ranged from 41 to 74 years (mean, 57.7 years), and their distribution was as follows: seven were 40 to 49 years, 10 were 50 to 59 years, 10 were 60 to 69 years, and three were over 70 years. Clinical problems were: headaches in eight, neurological deficits in 11, seizure in three, and tinnitus in one. These clinical problems were mild and unrelated to screened unruptured aneurysms in all. Six had a personal or family history of apoplexy. One was screened during the medical checkup in human dock. Thirty patients had 32 aneurysms; four were on internal carotid arteries, eight were on anterior cerebral arteries (one was distal anterior cerebral artery aneurysm and seven were anterior communicating artery aneurysms), 14 were on middle cerebral arteries, two were on posterior cerebral arteries, and four were on vertebro-basilar tree. The size of aneurysms varied; being $5 \mathrm{~mm}$ in eight patients, $6 \mathrm{~mm}$ in five, 8 and $9 \mathrm{~mm}$ in three each, $4,7,10,13$, and $22 \mathrm{~mm}$ in two each, and 18,20 , and $29 \mathrm{~mm}$ in one each. The aneurysms less than $10 \mathrm{~mm}$ in size were $78.1 \%$. Thus, unruptured cerebral aneurysms in the critical range of rupture could be screened by the noninvasive method.

In the 15 patients who did not receive operation, eight showed no change of condition, two worsened and four expired due to other causes, and one expired as a result of aneurysmal rupture. Of the 15 patients who were operated on, 11 showed no neurological morbidity and three had transient minor neurological symptoms postoperatively, and one experienced acute cardiac infarction 1 month after operation. The long-term results showed 10 patients in good condition, two in deteriorated conditions, and three who expired due to other causes.

The results show that these unruptured cerebral aneurysms should belong to a new category of unruptured cerebral aneurysms. Generally, unruptured cerebral aneurysms, once discovered, should be operated on from the standpoint of prevention of the subarachnoid hemorrhage. However, the indication for surgery is still controversial.
\end{abstract}

Key words: new category, unruptured cerebral aneurysms, screening, noninvasive method, computed angiotomography 


\section{I はじめに}

脳動脈瘤はいったん破裂すると約50〜60\%が死亡あるい は社会生活不能と社り，今な执その mortality，morbidity rate は高い,13,15,27)。我々はか子放て上り，脳動脈㨨治療の究 極の目的は，それを破裂前に大クリーニングし処置するこ とにあるとい5基本的理念比基つき，1979年以来高分解能 CTを用いた非浸襲的な脳血管 CT (computed angiotomography) の開発を行い，これを応用し，一般外来受讋者の なかから未破裂脳動脈瘤のスクリーニングを行ってき た2-4)。その結果，こ扎まてに無症状と考光られる未破裂

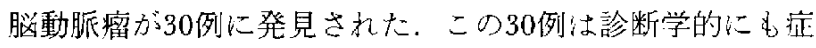
候学的にも，また脳動脈溜自体の持つ意義，治療而など種 々なる意味で徉来の未破裂脳動脈瘤とは趣を異にして未う り，未破裂脑動脈瘤の新しい概念として認識されるべきと 思われた，そこで本稿では，これら30例を分析し，杯裂 脳動脈瘤の新しい概念としての意義を明らかにしたい，

\section{III対象および方法}

1979年 4月より1984年 4 月まてに約1,700名の外来受診 者に対し脳血管 CT が施行さ扎た，脑血管 CTは，頭痛を 訴之受診したもの，過去に知覚・運動・言語障害々の他脎 血管発作が疑放れる症状老有したか現在有与るもの，高血

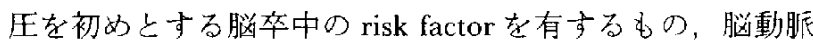
瘤を合併しやすい疾患を有するもの，脳卒中の既往・家族 歷を有するもの，人間ドックにて精查を希望するものなど を主たる対象とし，詳細な問診拈よび神経学的診察ののり に行われた，脳血管 CTの詳細は成㶳 ${ }^{4}$ に譲るが，概略は 以下のごとくである，GE·CT/T8800(9.6秒，10 mm ス ライス厚)を使用し，60\% Conray (meglumin iothalamate $282 \mathrm{mg}$ iodine $/ \mathrm{ml}) \quad 0.8 \sim 1.0 \mathrm{~m} / / \mathrm{kg}$ 量老用手的に $2 \sim 3 \mathrm{ml} /$ secの速さでbasilic あるいは antecubital vein から注入し， 静注開始20〜25秒後よりスキャンした。スキャンレべ心は canthomeatal line $の$ 上方 $25,30,35 \mathrm{~mm} て$, three-slice overlapping 法にてWillis 動脈輪索初好とする脳主幹動脈を描 出した。

\section{III結 果}

脳血管 CT て未未破裂脳動脈瘤が38例汇疑示れ，この5ち 脳血管撮影で囊状動脈溜が確認されたものは30例で苛っ た． 6 例は false positiveを示し，2 例は紡鍾型動脈瘤であ った。

30例の内訳江男性17例，女性13例で，年秢は41才から74 才にわたり，平均57.7才であった(Table 1)，受彰の契機 となった訴光、未破裂脳動脈留の大きさと部位, CT・脳
Table 1 Age range in 30 patients

\begin{tabular}{ccc} 
& \multicolumn{2}{c}{ No. of patients } \\
\cline { 2 - 3 } Age (year) & Male & Female \\
\hline $40-49$ & 5 & 2 \\
$50-59$ & 6 & 4 \\
$60-69$ & 5 & 5 \\
$70-79$ & 1 & 2 \\
\hline
\end{tabular}

Mean 57.7

血管撮影所見，およびそれらより碓定され心臸断，関重す る疾病の内訳を Table 2 に示した，受診の现機となった訴 光としては，頭痛か： 8 例（企体的 5 例，局所的 3 例），不全 単あるいは片麻痺が 5 例, 知覚障害, 言語障害, 意識消失

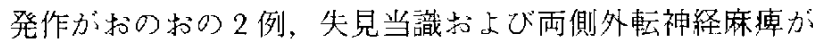
おのおの 1 例，てんかん，耳鳴が 1 例ずつあったが，これ

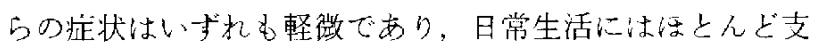
障をきたさない程度のものであった。また，白らあるい性 家族に脳卒中の舆往を有するものがおの沶の3例，人間卜゙ ックでの精查希望が 1 例であった。神経症状を有したるの の㐱断は, 脳梗塞が 7 例, 橋の小出血，モ中モヤ病，て九 かん，笳萎縮性側索硬化症がおのおの1例であった。睬卒 中の risk factor としては，高血圧症が 9 例に，糖尿病が 1 例红合併していた。なお，本稿で泟症が明らか心未破裂 脳動脈溜に起因するもの，たとえ軽度な白覚症状のみであ っても腰椎穿刺で血性䯣液を示したものは除外した。

米破裂脳動脈瘤の部位別頻度は，内頸動脈領域 4 個（後 父通動脈分岐部 3 個, $\mathrm{C}_{1} 1$ 個)，前大脳動脈領域 8 個(前交 通動脈 7 個，末梢部 1 個），中大脳動脈分岐部 14 個，後大 脑動脈 2 個，脳底動脈領域 3 個 (先端部 2 個，上小脳動脈 起始部 1 個)，椎骨動脈 1 個であった(Table 3)，大きさは $5 \mathrm{~mm}$ が 8 個でもっとも多く,ついで $6 \mathrm{~mm}$ が 5 個，8,9 mmがおのおの 3 個，4，7，10,13，22 mm がおのおの 2 個， 18, 20,29 mmがおの勒の1 個であり(Table 4)，10 mm 以

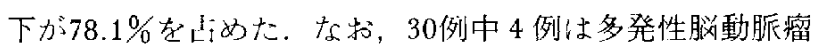
例 (4 個 1 例， 2 個 3 例)で志ったが，このらち $3 \mathrm{~mm}$ の中 大脳動脈瘤， $4 \mathrm{~mm}$ の眼動脈分岐部動脈瘤， $3 \mathrm{~mm}$ 扰上び $4 \mathrm{~mm}$ の脳底動脈瘤は脳血管 CT では false negative であっ た。スクリーニングされた大多数は単発性であり，李た多 発性の場合はもっとも破裂しや寸いとされている最大径の ものであったことも注目すべきで西るう。

30例の経過を Table 5 亿示した，15例の非手術群では8 例が不変，2例が他疾忠（モたもな病，脳梗塞）により悪 化，4例が他疾患(肺癌，胃癌，被款部出血，不詳）に上り 
Table 2 Summary of 30 patients with unruptured cerebral aneurysms screened by computed angiotomography

\begin{tabular}{|c|c|c|c|c|c|c|}
\hline $\begin{array}{l}\text { Case } \\
\text { No. }\end{array}$ & Primary clinical problems & $\begin{array}{c}\text { Size } \\
(\mathrm{mm})\end{array}$ & Site & $\begin{array}{l}\text { CT or angiographical } \\
\text { findings }\end{array}$ & Confirmed diagnosis & $\begin{array}{c}\text { Associated } \\
\text { disease }\end{array}$ \\
\hline 1 & headache (generalized) & 8 & rt. MCA & & & hypertension \\
\hline 2 & headache (generalized) & 5 & AComA & & & hypcrtension \\
\hline 3 & headache (generalized) & 4 & rt. MCA & & & \\
\hline 4 & headache (generalized) & 6 & rt. MCA & & & \\
\hline 5 & headache (generalized) & 29 & It. VA-PICA & & & \\
\hline 6 & headache (rt. occipital) & 5 & lt. MCA & & & \\
\hline 7 & headache (base) & 20 & BA top & & & \\
\hline $8^{*}$ & headache (rt. temporal) & $\begin{array}{r}22 \\
6\end{array}$ & $\begin{array}{l}\text { rt. MCA } \\
\text { lt. MCA }\end{array}$ & & & \\
\hline 9 & 1t. hemiparesis & 22 & lt. MCA & & cerebral infarction & hypertension \\
\hline 10 & lt. hemiparesis & 5 & It. MCA & LD near rt. IC & cerebral infarction & \\
\hline 11 & lt. hemiparesis & 8 & It. MCA & rt. MCA occlusion & cerebral infarction & hypertension \\
\hline 12 & rt. monoparesis (upper) & 13 & rt. MCA & & $\begin{array}{l}\text { amyotrophic lateral } \\
\text { sclerosis }\end{array}$ & \\
\hline 13 & lt. monoparesis (lower) & 5 & rt. PCA & LD near rt. IC & cerebral infarction & hypertension \\
\hline 14 & $\begin{array}{l}\text { sensory impairment } \\
\quad \text { (rt. face \& upper limb) }\end{array}$ & 10 & rt. MCA & multiple $\mathrm{LD}$ in lt. $\mathrm{BG}$ & cerebral infarction & hypertension \\
\hline 15 & $\begin{array}{l}\text { sensory impairment } \\
\text { (transient) }\end{array}$ & 18 & lt. PCA & & & \\
\hline 16 & speech impairment & 9 & ACiom A & multiple $\mathrm{LD}$ in lt. $\mathrm{BG}$ & cerebral infarction & \\
\hline 17 & speech impairment & 10 & BA top & LD in lt. frontal lobe & cerebral infarction & hypertension \\
\hline $18^{*}$ & disorientation & $\begin{array}{r}7 \\
13\end{array}$ & $\begin{array}{l}\text { It. ICPC } \\
\text { rt. C1 }\end{array}$ & $\begin{array}{l}\text { stenosis of bilateral } \\
\text { carotid forks }\end{array}$ & moyamoya disease & \\
\hline 19 & sixth nerve palsy (bilateral) & 9 & AComA & & & \\
\hline 20 & unconsciousness seizure & 5 & $\mathrm{BA}-\mathrm{SCA}$ & small $\mathrm{HD}$ in pons & pontine hemorrhage & \\
\hline 21 & unconsciousness seizure & 8 & AComA & & & \\
\hline 22 & seizure & 5 & lt. MCA & & epilepsy & \\
\hline 23 & tinnitus & 7 & $A \operatorname{Com} A$ & & & \\
\hline 24 & history of apoplexy & 9 & rt. MCA & $\mathrm{LD}$ in lt. BG & $\begin{array}{l}\text { putaminal hemor- } \\
\text { rhage }\end{array}$ & \\
\hline 25 & history of apoplexy & 4 & lt. ICPC & LD in lt. thalamus & thalamic hemorrhage & \\
\hline 26 & history of apoplexy & 5 & rt. ICPG & & cerebral infarction & hypertension \\
\hline 27 & family history of apoplexy & 6 & AComA & & & \\
\hline 28 & family history of apoplexy & 6 & lt. MCA & & & \\
\hline 29 & family history of apoplexy & 5 & AComA & & & $\begin{array}{l}\text { diabetes } \\
\text { mellitus }\end{array}$ \\
\hline 30 & $\begin{array}{l}\text { general workup in human } \\
\text { dock }\end{array}$ & 6 & lt. AGA (A2) & & & hypertension \\
\hline
\end{tabular}

${ }^{*}$ Case of multiple aneurysms. CT indicates computed tomography; MCA, middle cerebral artery; AComA, anterior communicating artery; VA-PICA, vertebral artery-posterior inferior cerebellar artery junction; BA top, basilar top; PCA, posterior cerebral artery; ICPC, internal carotid-posterior communicating artery junction; BA-SCA, basilar artery-superior cerebellar artery junction; ACA, anterior cerebral artery; LD, low-density area; HD, high-density area; IC, internal capsule; BG, basal ganglia region.

死亡，また1例( 45 才女性)が脳動脈瘤の破裂により死亡し た。15例の手術群では，術後経過は11例が良好であり，3 例飞一過件の失見当識, 言語障害が出現し，1例は 1 力月 後に急性心不全をきたした。長期観察では10例が術前の状 態と变らず良好で曹り，他疾患(脳梗寒)により2例が悪化 L, 3 例が死亡(1 例は前述の急性心不全例で 1 年後に, 1
例は 1 年 6 力月後消化管出血により，1例は不詳)した。

$$
\mathrm{N} \text { 考察 }
$$

脳動脈瘤の大多数は破裂により初めてその存在が確認さ れる。しかし，脳動脈瘤破裂に上る mortality，morbidity rateの高いことは前述した通りで女り，最近てはその治憭 
Table 3 Site distribution of 32 screened cerebral aneurysms

\begin{tabular}{lc}
\hline \multicolumn{1}{c}{ Site } & No. of ancurysms \\
\hline ICA (C1 portion) & 1 \\
ICPC & 3 \\
AComA & 7 \\
Distal ACA & 1 \\
MCA bifurcation & 14 \\
PCA & 2 \\
BA top & 2 \\
BA-SCA & 1 \\
VA-PICA & 1 \\
\hline
\end{tabular}

ICA indicates internal carotid artery.

Table 4 Size distribution of 32 screened cerebral aneurysms

\begin{tabular}{cc}
\hline Maximal diameter $(\mathrm{mm})$ & No. of aneurysms \\
\hline 4 & 2 \\
5 & 8 \\
6 & 5 \\
7 & 2 \\
8 & 3 \\
9 & 3 \\
10 & 2 \\
13 & 2 \\
18 & 1 \\
20 & 1 \\
22 & 2 \\
29 & 1 \\
\hline
\end{tabular}

の限界上非侵襲的な検查方法の開発により，未破裂脳動脈 瘤の発見と治療に対する関心が高まってきている。我々は か教て上り，クモ膜下出血の予防的見地加的末破裂脑動脈 瘤のスクリーニングの重要性を感し，1979年以来非侵襲的 な脳血管 CTを用いてそのスクリーニングに努力してき た2-4!。従来，未破裂脸動脈瘤はその汪とえどがク王膜下 出血例に打汁る多発吽脳動脈瘤として，あるい:脳堹瘍， 頭部外傷など他疾患の検查中偶然に発見されたものであ り，発見方法としては侵襲的な脳血管撮影による为のが多 かった。こ机に対し，本稿で提示された 脳血管 CTによる一般外来受診者を対象としたスクリーニ ングシステムの一環として発見されたものであり，末ずこ こにこの30例の新たな診断学的特徴が見い出される。

症候学的に㕛ると，30例の受䛦の契機となった訴えは Table 2 に示したごとく，頭悀がもっとも多く，種々なる 軽微な神経症状，不定愁訴の症候群がこれに続く，未破裂 脳動脈瘤により頭痛が発生する機序としては，脳動脈瘤の
増大による血管壁の伸展，周囲組織入の刺激，血管壁内小 出血による sensory nerve ending $の$ 機械的・化学的刺激が 考えられている20,23!。頭痛を訴えた8例では全体痛が 5 例, 部分痛が 3 例であったが，この5 前者の1例の訴え は媛頭部を主とする全体の鈍痛（椎骨動脈瘤，29 mm)であ り，後者の 2 例の之扎は“頭のンンが痛い”(脳底動脈瘤, $20 \mathrm{~mm}$ )，“右側頭部がズキズキ寸る”(右中大脳動脈瘤， $22 \mathrm{~mm}$ )であった。この3 例の頭痛は，その性質と動脈瘤 の大きさ，部位から前述のごとき発生機序で説明され，頭 痛之未破裂脳動脈瘤の存在が関係付けられ，いわゆる“症

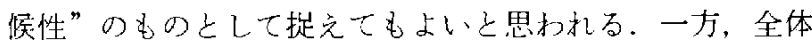
痛を訴えた残りの4 例と部分痛を訴之た残りの1例では， いずれも頭痛の性質や持続時閒，脳動脈瘤の局在(中大脳 動脈瘤 4 例，前交通動脈瘤 1 例)，大きさ $(4 \sim 8 \mathrm{~mm})$ など から症状上未破裂脳動脈瘤の存在との関係索明只か心する ことは相難であった。专た，軽微ながら過去あるいは現在 神経症状を有していた11例中 8 例で臨床骖断学的，レント ゲン学的に未破裂脳動脈瘤の存在とはまったく関係を有さ

Table 5 Outcome of 30 patients with screened unruptured cerebral aneurysms

Non-operated cases:

\begin{tabular}{|c|c|}
\hline Outcome & lo. of patients \\
\hline Unchanged & 8 \\
\hline $\begin{array}{l}\text { Worsened from other causes } \\
\text { cerebral infarction } \\
\text { moyamoya disease }\end{array}$ & $\begin{array}{l}2 \\
1 \\
1\end{array}$ \\
\hline $\begin{array}{l}\text { Death from other causes } \\
\text { putaminal hemorrhage } \\
\text { stomach cancer } \\
\text { lung cancer } \\
\text { unknown }\end{array}$ & $\begin{array}{l}4 \\
1 \\
1 \\
1 \\
1\end{array}$ \\
\hline Death from aneurysmal rupture & 1 \\
\hline \multicolumn{2}{|l|}{ Operated cases: } \\
\hline Outcome & $\begin{array}{c}\text { No. of } \\
\text { patients }\end{array}$ \\
\hline \multicolumn{2}{|l|}{ Course within 1 month after operation: } \\
\hline No neurological morbidity & 11 \\
\hline Transient neurological morbidity & 3 \\
\hline $\begin{array}{l}\text { Worsened from other cause (acute heart failure } \\
1 \text { month after operation) }\end{array}$ & 1 \\
\hline \multicolumn{2}{|l|}{ Long-term outcome: } \\
\hline Unchanged prepared preoperative condition & 10 \\
\hline $\begin{array}{l}\text { Worsened prepared preoperative condition from } \\
\text { other cause (cerebral infarction) }\end{array}$ & 2 \\
\hline $\begin{array}{l}\text { Death from other causes } \\
\text { heart failure } \\
\text { gastrointestinal bleeding } \\
\text { unknown }\end{array}$ & $\begin{array}{l}3 \\
1 \\
1 \\
1\end{array}$ \\
\hline
\end{tabular}


ない責任病巣が確定された。不定愁訴群ではをと意味付け はさらに困難である。市なかち，発見された未破裂脸動脈 瘤の存在法その患者心とってまったく子期世ぬ，からその 時点ではすべてに優先する重大な意味を持つものであった ことがこの seriesの最大の特徽である。

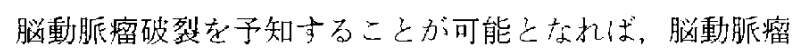
の治療成績恃飛躍的に向上することは想像に難くない，そ の試みとして，破裂脳動脈瘤症例の破裂部の症状老 retro-

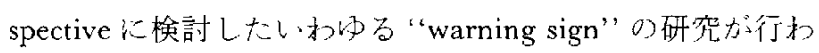
扎ている211. 最近ではDrake?, Heros $\vec{b}^{131}$ bこの warning sign 重視し, 脳動脈瘤を大破裂前に発見寸ることの 重要性を説き，末破裂脳動脈瘤に対する認識を高わ，一般 人扰上び一般医師を答蒙する必要性を指摘している。しか し，今回の seriesでは無症状のもの，CT索よ゙の娭査によ りい执わる warning signとさ之言いがたい症状のものが

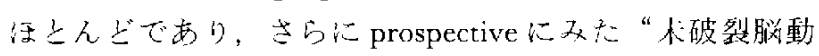
脈瘤の症候学”とでも言らべき分野の研究が待たれる。

実際に riskの女る患者をよ゙のよらに同定しスクリー二

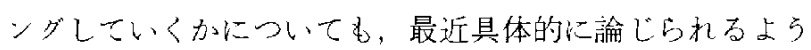
になってきている、スクリーニングの guidelineとしては, 20〜60才台て頸動脈 $の$ fibromuscular dysplasia, polycystic kidney, 大動脈の coarctation, hypertrophy, Ehlers-Danlos 症候群，Marfan 症候群, pseudoxanthoma elasticum $\lesssim\llcorner$ 脳動脈瘤を合併しや寸い疾患捄よび脳動脈瘤の家族歴を有

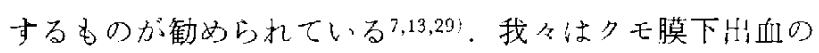
予防的見地からるスクリーニングは可能流かきり広く行わ れるべきであると考えているが，実際には種々なる制約が あり，現在の上ころ寒現困難である。したがって我々は， 現時点では前述のごとき guidelineに加えて, 軽微であっ て子 Table 2 心示されたような臨床的問題を有するもの， ロントロールされがたい高血圧症など脳卒中の risk factor を有寸るもの，本人括よび家族に脳動脈瘤あるいはそれ以

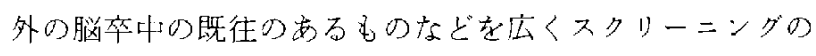
対象上寸べきである考它ている、また，人間ドックから スクリーニングされた例もあり，今後スクリーニングンス テムの向を考之るトで興味深い、本稿の論旨からは除外 したが，視力・視野障吉，動眼神経麻痺などの神経生迫症 状，頡痛圭初め上する兴血管発作の既往のあるもの一い小 ゆる warning sign の疑いが持たれた症例一屯，先の対象 であることは言うまであない。さらに，最近では未破裂脳 動脈瘤に起因寸ると考えられる脳虚血発作が報告され注目 されており，やはりスクリーニングの対象となるら。スク リーニングの方法としては，高分解能 CT(我々の脳血管 CTがこれに相当)やdigital subtraction angiography, electronic stethoscope ${ }^{22 !}, さ ら に は$ 最近の magnetic resonance imagingなどの非あるいは低侵襲性の検査方法の活用が期 待される。

さて、スタリーニングさ扎た末破裂脳動脈溜はいか詨 処さ机るへきか。この命題は最近急速に注日を集め，論議 の的になっている. 占くはHeiskanen $b^{12}$, Mount $5^{181}$,

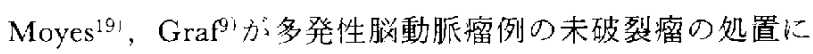
つ、て報告し，無処置群の破裂の危険度はかなり高いと述 心，最近ではDrake が無処置瘤の17\%が，Heiskanen ${ }^{11}$ 沈11.5\%がのる破裂したと報告している。手術成績から の報告では，Wirth $5^{31 !}$ の cooperative study で morbidity

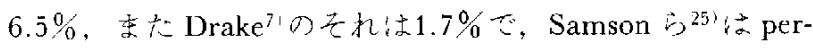
manent morbidicy $6.3 \%$, transient morbidity $14.3 \%$ と報告 L. mortalityはい执わ0\%である。Jain ${ }^{14)}$, Salazar $^{24)}$ の報告名问様で，どの報告でも低い mortality，morbidity rateでかり，この結果から報告者はいずれる未破裂脳動脈 樨口対才る積極的な手術的処置を推桨している。

ここて臨床上もっとも問題となる事柄は，発見された未 破裂脳動脈瘤が破裂する危険のある動脈瘤であるか否かで ある，こり問題に関しては，今のところ破裂脳動脈瘤の年 龄別発生頻度や大きさ，末破裂脳動脈瘤の natural history，およびそれに基ついて推訃学的に論じられている に留まる。このらち脳動脈瘤の大きさがその破裂にもっと も関保深い因子であることは，才でに多くの報告のなかで 述べられている. McCormick らが は $2010 \mathrm{~mm}$ の動脈瘤 の41\%が，また11〜15 mm $987 \%$ が破裂例であったと し，Freytag ${ }^{8}$ は破裂脳動脈瘤の66\%は 6 10 mm のささ

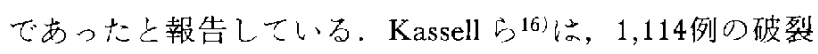
脳動脈瘤の cooperative studyでその71\%は10 mm 以下, さらに13\%は $5 \mathrm{~mm}$ 以下であったとし，10 $\mathrm{mm}$ 以下の脳 動脈瘤は破裂の危険性が高いことを指摘し，少なくとも 5 10 mm の脳動脈瘤は処置されるべきでると述べてい る。一方，Crompton ${ }^{5}$ は破裂扎よび未破裂脳動脈瘤の病 理学的検索により，破裂脳動脈溜の平均は $5 \mathrm{~mm}$ であり， 脳動脈瘤が $4 \mathrm{~mm}$ 以上になるとその壁には壁内への細胞浸 潤を初めと寸る破裂に至名上考光られる病理变化が起こ一 ていることを証明し，脳動脈瘤破裂の critical diameter $4 \mathrm{~mm}$ の大さに求めている，Suzuki 5 261 も林破裂脳動脈 瘤の大きさと脳動脈瘤壁との関倸をやはり病理学的に検討 し，脳動脈瘤が $4 \mathrm{~mm}$ から $5 \mathrm{~mm}$ になると壁にきわかて薄 い菌所がみられるよう沈なると報告している。我々の的 vivoに打胡る末破裂脳動脈瘤の壁の形態上性状に関与る研 究りでも，脸動脈瘤は $4 \mathrm{~mm}$ 以上になると壁内出血，壁の 菲薄化， multiloculationなどさまざなな变化を示し，破㤠 しやすい状態にあることを観察している。したかっててこ critical rangeの大きさの未破裂脳動脈瘤をいか心多く 
スクリーニングするかが重要なポイントとなってくる。な ぜなる， critical rangeの脳動脈瘤坴発見することは，その 破裂な未然に防ぐkeyとなるからである，我々の脳血管 CTを用いたスクリーニングではTable 4のごとく4〜10

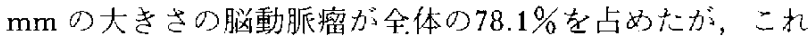

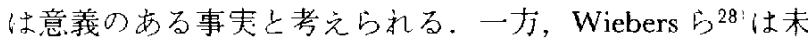
破裂脳動脈瘤が破裂に至るもっとも重要な因子はその大き さで㧍り，10 $\mathrm{mm}$ 越克ると破裂する危険度が高まると いら報告をしているが，この報告には多くの反論もるる。

未破裂脳動脈瘤の natural historyに関しては，い未仕定 説はない、Winn $5^{30}$ 虫その年間破裂率を $3 \%$ 程度乙推察 し，またDell ${ }^{6)}$ は脑動脈溜の年歯による破裂率を推訃学的 に考察し，20３0才ではその牛涯破裂率は16\%を越光るが 40，50，60才では14.4，10.3，4.68\%であり，若年者の生洼 破裂率の高いこと在示扵興味ある報告をしている。

現在，末破裂脳動脈瘤に関する未解決の諸間題が山積し ているなかで，その処置について結論を出すのは無論早計 ではあるが，前述してきたごとき文献的背景とスクリー二 ングされた脸動脈瘤の持つ意味の重要性から，その手術啇 応は以下の3要素が考察され，沈めら机るべきである々考 えている、与なわち，(1脳動脈瘤自体の持つ因子一大き さ，形態，部位，成長過程，(2)秛裂脳動脈瘤を有してい る患者自身の持つ因子一年踖，合併疾患の有無および程 度，社会的背景，(3)社会的因子一施設，術者の技量であ る。ことに本稿で提示されたごとき絧動脈瘤において!去， それ自体の持つ意義が患者にとって第一義的であるため， いっそう慎重な対処が要求される。現時点では我々は，60
才台本でで，合併疾患を有する症例では脳動脈瘤の存在意 義が合併疾患に勝る場合，また脳動脈瘤の大きさが $4 \mathrm{~mm}$ を越完る場合に原則的に手術的処置を考えている。ささらに 症例を重称て未破裂脳動脈瘤の手術適灾は決められるべき であるが，一破裂脳動脈瘤も破裂直前まではいわゆる未 破裂脳動脈瘤であった䚿ですり口，东た脳動脈瘤は血流か ら遮断されないかぎり破裂の危険性があること致改めて 認識す心゙き事夹であ万弓。

さて，我々はこれ东で述べてきたよらな新しい慨念を加 学て未破裂脳動脈瘤をTable 6 のごとく分類し，打の沶の の意義付けを行っている。本稿で提示された未破裂脳動脈 瘤は，この分類によれば group $\mathrm{N}$ の範嶹に属し，未破裂 脳動脈瘤のなかではもっ上も重要な意味を持わ，しかも非 あるい:低侵襲性の診断機械の発展上普及に上りこの group $\mathbf{N}$ に属する破裂脳動脈瘤のスクリーニングれ る機会は东す东増大するであるらことは想像に難くな 、.ク七膜下出血の予防的見地から，未破裂脳動脈滥，こ とに group $\mathrm{N}$ のスクリーニングと治寮は脳神経外科医に 課せられた解決しなければならない大きな佮題で亦る。

\section{$V$ ま $め$}

脳血管 CTを用いて一般外来受哙者のなかから非侵襲的 にスクリーニングされた柀裂脳動脈瘤30例を提示した。 これらの未破裂脳動脈瘤は，いずれも無症状加日常生活に 支障劣さたさない程度の軽微な神経证状を有した症例のな かから非侵襲的にスクリーニングされたすのであることが 従来のそ机と異なる大きな特徴である，したがって，発見

Table 6 New classification of unruptured cerebral aneurysms

\begin{tabular}{|c|c|c|c|c|}
\hline Group & Criteria & Examination & Significance & Treatment \\
\hline I & multiple intact aneurysms in patients with SAH & $\begin{array}{l}\text { angiography, } \\
\text { CCAT, DSA }\end{array}$ & $\begin{array}{l}\text { asymptomatic; } \\
\text { second aneurysm }\end{array}$ & $\begin{array}{l}\text { surgical treatment should be } \\
\text { considered, when the rup- } \\
\text { tured aneurysm is treated } \\
\text { successfully }\end{array}$ \\
\hline II & $\begin{array}{l}\text { intact aneurysm discovered incidentally during } \\
\text { investigation of diseases other than SAH }\end{array}$ & $\begin{array}{l}\text { angiography, } \\
\text { CGAT, DSA }\end{array}$ & $\begin{array}{l}\text { asymptomatic; } \\
\text { first aneurysm, but it is } \\
\text { secondary to patient }\end{array}$ & $\begin{array}{l}\text { treatment is dominated by } \\
\text { the primary disease }\end{array}$ \\
\hline III & $\begin{array}{l}\text { aneurysm with compression or ischemic clinical } \\
\text { signs, and minor subjective symptoms due to } \\
\text { aneurysm }\end{array}$ & $\begin{array}{l}\text { CCAT, DSA, } \\
\text { angiography }\end{array}$ & $\begin{array}{l}\text { symptomatic; } \\
\text { the aneurysm itself is } \\
\text { primary to patient }\end{array}$ & $\begin{array}{l}\text { surgical treatment should be } \\
\text { done to prevent SAH }\end{array}$ \\
\hline IV & $\begin{array}{l}\text { aneurysm screened by noninvasive method } \\
\text { in healthy person } \\
\text { in patient with risk factor of cercbrovascular } \\
\text { disease } \\
\text { in patient with disease that predispose to the } \\
\text { formation of aneurysm } \\
\text { in parient with minor subjective symptoms } \\
\text { not related to aneurysm }\end{array}$ & $\begin{array}{l}\text { CCAT, DSA, } \\
\text { ESS, MRI }\end{array}$ & $\begin{array}{l}\text { asymptomatic; } \\
\text { the aneurysm itself is } \\
\text { primary to patient }\end{array}$ & $\begin{array}{l}\text { surgical treatment should be } \\
\text { considered to prevent } \\
\text { SAH, but controversial } \\
\text { at present }\end{array}$ \\
\hline
\end{tabular}

SAH indicates subarachnoid hemorrhage; CCAT, cerebral computcd angiotomography; DSA, digital subtraction angiography; ESS, electronic stethoscope; MRI, magnetic resonance imaging. 
された本破裂脳動脈㨨はその患者によって真に第一義的て ある。発見された未破裂脳動眽瘦に対しては原則的には手 術的処置がとられるべきを考えるが，その適心には慎重で なければならず，脳動脈瘤自体の持つ因了，脳動脈瘤を有 する患者自身の持つ因子，施設や術者心持つ因子の3 要素 が考慮されるべきで方る。方膜下出血の予防的見地か ら，未破裂脳動脈瘤の非侵襲的なスクリーニングと治療は きかかて重要な問題である。

稿劣終える汇当り，本研究に御協力頂き重し心岡山大学脳神経 外科桜井勝先生, 佐藤 透 先牛, 須賀正和 先生, 松山市民 病院脑神経外科角㫧典生 先生, 国塩勝二先生, 和昌会貞本病 院院長 貞本和彦 先生, 同院脳神経外科 福并㤵二 先生に感謝致 します。

本論文の要旨俚，第25回日本神経学会総会(1984年 5 月，札沅） 比いて発表した。

\section{文献}

1) 浅利正二, 国㙁勝三, 角南典生, 山本落司, 福井啓二, 貞 本和应：脳血管 CTてスクリーニングされた未破裂脳動脈瘤 の検討。第43回日本脳神経外科学会総会. 一茟， 1984

2) 浅利正二，桜井 勝, 山本祐司, 鉿木健一, 貞本和彦 : Incidental asymptomatic aneurysm の診断におけ枋るCT の果たす役 割. 脳上神 33: 115-123, 1981

3) Asari $S$, Satoh $T$, Sakurai $M$, Yamamoto $Y$, Sadamoto $K$ : Delineation of unruptured cerebral aneurysms by computerized angiotomography. $J$ Neurosurg 57: 527-534, 1982

4) Asari S, Yamamoto Y: Computed Angiotomography of the Brain. Tokyo, Neuron, 1985, pp 80-123

5) Crompton MR: Mechanism of growth and rupture in cerebral berry aneurysms. Bril MedJ 1: 1138-1142, 1966

6) Dell S: Asymptomatic cerebral aneurysms: Assessment of its risk of rupture. Neurosurgery 10: 162-166, 1982

7) Drake CG: Management of cerebral aneurysm. Stroke 14: 273283, 1983

8) Freytag E: Fatal rupture of intracranial aneurysms: Survey of 250 medicolegal cases. Arch Path (Chicago) 81: 418-424, 1966

9) Graf CJ: Prognosis for patients with nonsurgically-treated aneurysms. Analysis of the cooperative study of intracranial aneurysms and subarachnoid hemorrhage. $J$ Neurosurg 35: 438443, 1971

10) Hashimoto $\mathrm{N}, \mathrm{Handa} \mathrm{H}$ : The fate of untreated symptomatic cerebral aneurysms: Analysis of 26 patients with clinical course of more than five years. Surg Neurol 18: 21-26, 1982

11) Heiskanen $O$ : Risk of blecding from unruptured aneurysms in cases with multiple intracranial aneurysms. J Neurosurg 55: 524526, 1981

12) Heiskanen $O$, Marttila I: Risk of rupture of a second aneurysm in patients with multiple aneurysms. J Neurosurg 32: 295-299,
1970

13) Heros RC, Kistler JP: Intracranial arterial aneurysm-An update. Stroke 14: 628-631, 1983

14) Jain KK: Surgery of intact intracranial aneurysms. J Neurosurg 40: 49.5-498, 1974

15) Kassell NF, Drake CG: Timing of aneurysmal surgery. Neurosurgery 10: 514-519, 1982

16) Kassell NF, Torner JC: Size of intracranial aneurysms. Neurosurgery 12: 291-297, 1983

17) McCormick WF, Acousta-Rva GJ: The size of intracranial saccular aneurysms: An autopsy study. J Neurosurg 33: 422-427, 1970

18) Mount LA, Brisman R: Treatment of multiple intracranial ancurysms. J Neurosurg 35: 728-730, 1971

19: Moyes PD: Surgical treatment of multiple aneurysms and of incidentally-discovered unruptured aneurysms. I Neurosurg 35: 291-295, 1971

20) Nyström SHM: Development of intracranial aneurysms as revealed by electron microscopy. J Neurosurg 20: 329-337, 1963

21) Okawara $S$ : Warning signs prior to rupture of an intracranial aneurysm. J Neurosurg 38: 575-580, 1973

22) Olinger CP, Wasserman JF: Electronic stethoscope for detection of cerebral aneurysms, vasospasm and arterial disease. Surg Neurol 8: 298-312, 1977

23) Ray BS, Wolf HG: Experimental studies on headache: Painsensitive structures of the head and their significance in headache. Arch Surg (Chicago) 41: 813-856, 1940

24) Salazar JL: Surgical treatment of asymptomatic and incidental intracranial aneurysms. J Neurasurg 53: 20-21, 1980

25) Samson DS, Hodosh RM, Clark WK: Surgical management of unruptured asymptomatic aneurysms. $J$ Neurosurg 46: 731-734, 1977

26) Suzuki J, Ohara H: Clinicopathological study of cerebral aneurysms. Origin, rupture, repair, and growth. I Neurasurg 48: 505-514, 1978

27) Whisnant JP, Phillips LH II, Sundt TM Jr: Aneurysmal subarachnoid hemorrhage: Timing of surgery and mortality. Mayo Clin Proc 57: 471-475, 1982

28) Wiebers DO, Whisnant JP, O'fallon WM: The natural history of unruptured intracranial aneurysms. $N$ Engl J Med 304: 696698,1981

29) Wilkins RH: Update-subarachnoid hemorrhage and saccular intracranial aneurysms. Surg Neurol 15: 92-101, 1981

30) Winn HR, Richardson AE, O'Brien W, Jane JA: Long-term prognosis in untreated cerebral aneurysms: II. Late morbidity and mortality. Ann Neurol 4: 418-426, 1978

31) Wirth FP, Laws ER Jr, Piepgras D, Scott RM: Surgical treatment of incidental intracranial aneurysms. Neurosurgery 12: 507511,1983

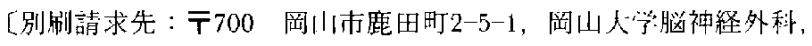
浅利正二] 